\title{
THE EFFECT OF REPRESENTATIVENESS, AVAILABILITY, ANCHORING, RISK PERCEPTION, AND HERDING ON INVESTMENT DECISIONS SYARIAH INVESTORS
}

\author{
Rico Priandana Loris ${ }^{1)}$, Prabowo Yudo Jayanto ${ }^{2)}$ \\ Universitas Negeri Semarang ${ }^{1)}$, Universitas Negeri Semarang ${ }^{2}$ \\ riicopl@gmaill.com ${ }^{1)}$
}

\begin{abstract}
Investors do not always think rationally but sometimes think irrational. Decision-making based on irrational thinking is influenced by a psychological bias which often leads to wrong decisions. This study aims to find empirical evidence of the influence of representativeness, availability, anchoring, risk perception, and herding on the investment decisions of sharia investors who open stock accounts at Phintraco Sekuritas Semarang. The population in this study were investors who have opened Islamic stock accounts at Phintraco Sekuritas Semarang. The sample is respondents who have opened Islamic stock accounts at Phintraco Sekuritas Semarang. The sampling technique used was simple random sampling and data collection techniques used a questionnaire. The data were analyzed using descriptive analysis and Structural Equation Modeling (SEM). The results showed that representativeness, anchoring, risk perception, and herding have a significant positive effect on the investment decisions of Islamic investors. Meanwhile, the availability variable does not affect investment decisions in Islamic investors.
\end{abstract}

Keywords: Investment Decision; Representativeness; Availability; Anchoring; Risk Perception; Herding; Behavioral Finance.

*Corresponding author

Email: riicopl@gmaill.com

DOI: https://doi.org/10.33369/j.akuntansi.11.1.81-92

\section{INTRODUCTION}

In today's modern era, the need for investment is very important, which is related to the finances of an individual or an organization or entity (Rakhmatulloh \& Asandimitra, 2019). The reason is that the rate of return given to investment in the capital market is quite high. The desire to invest shows an assessment of the company which is reflected in the stock price itself (Septyato \& Dewanto, 2016). From an investor's point of view, stocks provide an alternative for investors to choose to invest in the short or long term, which in general will attract investors to invest their funds (Hadi, 2013).

In line with the improving economic conditions in Indonesia, the level of investment in the financial sector is also increasing. According to Islam, investment is an element of muamalah activity, where Islam considers investment as a necessity to be carried out so that property becomes productive and can bring benefits to others. This is also strengthened by the existence of an explicit prohibition, that Islam does not allow the hoarding of assets. One of the capital market instruments is by sharia principles, namely Islamic stocks. Sharia shares are evidence of ownership of a company that fulfils the characteristics of sharia as determined by the National Sharia Council of the Indonesian Ulema Council (DSN-MUI) (Nasional, 2003).

Based on data from the Indonesian Central Securities Depository (KSEI), it shows an increase in total investors in Indonesia. At the end of 2019, total investors in the Indonesian capital market reached 2.4 million Single Investor Identification(SID), which increased significantly from 1.61 million SID in the full year 2018 period. SID is the single number of investors that describes the ownership of the issued capital market investor identity. by KSEI (Wareza, 2019). It can be seen from these data that investment in the capital market, especially stock investment in Indonesia, is a popular part of the community (Khairunizam \& 
Isbanah, 2019). In line with the development of the capital market in Indonesia, now apart from offering conventional financial instruments such as stocks, bonds and mutual funds, currently several capital market financial instruments that meet the requirements of Islamic law (Islamic Financial Instruments) have been offered. This was carried out to satisfy the interests of investors who wish to invest with reference to a number of sharia principles (Yafiz, 2008).

In terms of performance, Islamic stocks did not disappoint and showed good growth, but in terms of market capitalization growth that has not been able to compete with LQ45 stock market capitalization, raises many general questions regarding the true growth of Islamic stocks (Darmawan \& Anwar, 2019). Large capitalized stocks are a target for investors to make long-term investments, because of the good growth opportunities for the company, along with dividends and the relatively low risks involved (Silviyani et al., 2014). It can be said that market capitalization is one of the guidelines that show how actively or often the shares are traded (Darmawan \& Anwar, 2019). When viewed from this, even though the total growth of Islamic stocks increases every year, Islamic stocks are not as actively traded like other stocks in the LQ45 index. This is due to the tendency of investors to be trapped by a cognitive bias that assumes that stocks in the LQ45 index provide a higher return guarantee than stocks on other indices. So that investors tend to be more active in stocks on the liquid stock index, namely LQ45 than on the liquid sharia stock index, namely the Jakarta Islamic Index.

Emotional involvement in making decisions makes investors act irrationally, even though in investing, investors must be able to make the right decisions because investing has a large enough risk. Investment decisions in risky situations are based on several factors such as psychological, objectivity, and emotional, but investors must realize that in addition to being able to provide high returns. investing in stock instruments also has a large enough risk if they are not selective in choosing the company to invest in (Prabawa et al., 2015). In practice, many individual investors commit irrational acts and make systematic mistakes on the estimates they make based on the information they obtain. Errors in interpreting information will affect the wealth of the investor's portfolio (Kartini \& Nugraha, 2015).

In making decisions, individuals can make mistakes systematically both in the way of thinking, for example, being too confident in the abilities of an investor and too dependent on past experiences (Ritter, 2003). Representativeness is decision making based on stereotypical thinking that will cause investors to make wrong financial decisions, namely financial decisions that do not maximize profits (Sina, 2014). Research by Rasheed et al., (2018), Khan, HH et al (2017), Waweru et al (2014), Rekik and Boujelbene (2013) stated that representativeness has a positive effect on investment decisions. In contrast to the research of Kurniawati \& Sutrisno (2019) and Shah et al (2018) which state that representativeness does not have a positive effect on investment decisions.

The next factor that can affect investment decisions is availability. Availability is a behavioural bias characterized by a tendency to rely on information that is already available (Pompian, 2012). Research by Rasheed et al (2018), Khan, HH et al (2017), Khan (2015), Ikram (2016) states that availability has a positive effect on investment decisions, whereas research by Kurniawati \& Sutrisno (2019) found results that stated availability had no effect on Investation decision.

An individual's investment decision can also be affected by anchoring. Anchoring is a cognitive heuristic that is caused by the tendency of individuals to judge prices based on initial information obtained (Supramono et al., 2018). This research conducted by Luong, et al (2011), Muriithi (2014), Masomi and Ghayekhloo (2010), and Waweru et al (2014) stated that anchoring has a positive influence on investment decisions. However, it is not in line with Budiman \& Ervina (2020) research which states that anchoring has no effect on investment decisions. 
In making investment decisions, a person is also influenced by their perceptions of seeing a risk. Perception of risk is an assessment of a person in a risky situation that depends on the psychological characteristics and condition of the person (Wulandari \& Iramani, 2014). Research by Baghani \& Sedaghat (2016), Aren \& Zengin (2016) states that risk perception has a positive effect on investment decisions, while research by Khairunizam and Yuyun Isbanah (2019), Alquraan et al., (2016), and Pradikasari \& Isbanah (2018) stated that risk perception has no positive effect on investment decisions.

Herding is the behaviour of individuals in making decisions that tend to make decisions based on majority decisions (Subash, 2012). Research Vijaya (2016), Ngoc (2013), Luong \& Thi Thu Ha (2011) and Khairunizam \& Yuyun Isbanah (2019) stated that herding has a positive effect on investment decisions. However, it is not in line with the research of Alquraan et al. (2016) and Setiawan et al., (2018). The purpose of this study is to examine the effect of representativeness bias, availability bias, anchoring bias, risk perception, herding bias on investment decisions of Islamic investors. Seen in previous studies, there are still inconsistencies between the variables studied so that further research is still necessary.

\section{RESEARCH METHODS}

This research is classified as quantitative research (quantitative research). The population of this research is all customers who already have Islamic stock accounts at Phintraco Sekuritas Semarang city branch. This population withdrawal is because the customer has experience in buying Islamic stocks. The population in this study amounted to 1050 customers who have opened Islamic stock accounts. The technique used in sampling is simple random sampling. The minimum sample calculation technique used is through the use of the Slovin formula, namely:

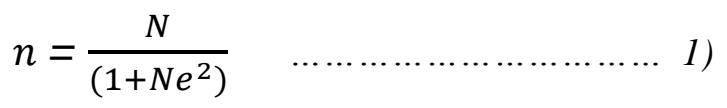

Information:

$\mathrm{n}$ : Number of Samples

$\mathrm{N}$ : Total Population

e : Total error tolerance (ET / Error Tolerance)

In this study, an error tolerance of $10 \%(0.1)$ is taken. So, the calculations using the Slovin formula are as follows:

$$
\begin{aligned}
n & =\frac{1050}{(1+1050(0,1) 2} \\
& =91,3
\end{aligned}
$$

Based on the above calculations, this study requires a minimum sample of 91.3 respondents or rounded to 91 respondents, so the sample used in this study is 91 Islamic investors at Phintraco Sekuritas Semarang city branch. The independent variables in the study were representativeness, availability, anchoring, risk perception, and herding, while the dependent variable in the study was investment decisions. The operational definition can be seen in Table 1 as follows:

Table 1 Operational Definition of Variables

\begin{tabular}{lllll}
\hline No. & Variable & Definition & Indicator & Scale \\
\hline 1. & Investation & An investment decision is a & 1. Knowing the expected rate & Likert \\
decision & process of selecting an & of return & $1,2,3,4,5$ \\
& & alternative from the various & 2. Knowing the risks faced & (Preston \& \\
& & 2012) & 3. Determine investment time. & Colman, \\
& & & 2000)
\end{tabular}


THE EFFECT OF REPRESENTATIVENESS, AVAILABILITY, ANCHORING, RISK PERCEPTION, AND HERDING ON INVESTMENT DECISIONS SYARIAH INVESTORS

Rico Priandana Loris and Prabowo Yudo Jayanto

\begin{tabular}{|c|c|c|c|c|}
\hline No. & Variable & Definition & Indicator & Scale \\
\hline 2. & Representativeness & $\begin{array}{l}\text { Representativeness is making } \\
\text { decisions based on stereotypical } \\
\text { thinking or analogies and will } \\
\text { cause investors to make wrong } \\
\text { financial decisions, namely } \\
\text { financial decisions that do not } \\
\text { increase yields (Shefrin, 2007). }\end{array}$ & $\begin{array}{l}\text { 1. Failure to consider sample } \\
\text { size } \\
\text { 2. Ignoring basic reality } \\
\text { 3. Consider certain } \\
\text { characteristics as } \\
\text { representative of all scenarios }\end{array}$ & $\begin{array}{l}\text { Likert } \\
1,2,3,4,5 \\
\text { (Preston } \\
\text { and } \\
\text { Colman, } \\
\text { 2000) }\end{array}$ \\
\hline 3. & Availability & $\begin{array}{l}\text { Availability is a heuristic } \\
\text { behaviour that refers to a } \\
\text { person's tendency to rely on } \\
\text { information that is already } \\
\text { available (Khan et al., 2017). }\end{array}$ & $\begin{array}{l}\text { 1. Decisions are made based } \\
\text { solely on the willingness to } \\
\text { receive existing information, } \\
\text { 2. Assuming other investors } \\
\text { will also do the same and have } \\
\text { easy access to information, } \\
\text { 3. Make decisions based on } \\
\text { predictions. }\end{array}$ & $\begin{array}{l}\text { Likert } \\
1,2,3,4,5 \\
\text { (Preston } \\
\text { and } \\
\text { Colman, } \\
\text { 2000) }\end{array}$ \\
\hline 4. & Anchoring & $\begin{array}{l}\text { Anchoring is the tendency of } \\
\text { individuals to judge prices based } \\
\text { on initial information obtained } \\
\text { (Supramono, 2018) }\end{array}$ & $\begin{array}{l}\text { 1. Relying on past } \\
\text { experiences, } \\
\text { 2. Ignoring new information } \\
\text { 3. Set the price before buying } \\
\text { or selling shares }\end{array}$ & $\begin{array}{l}\text { Likert } \\
1,2,3,4,5 \\
\text { (Preston } \\
\text { and } \\
\text { Colman, } \\
\text { 2000) }\end{array}$ \\
\hline 5. & Risk Perception & $\begin{array}{l}\text { Risk Perception is an investor's } \\
\text { view that may not get the return } \\
\text { as expected. } \\
\text { (Trang \& Tho, 2017) }\end{array}$ & $\begin{array}{l}\text { 1. Feeling at risk in the capital } \\
\text { market marked with } \\
\text { "warning" signs; } \\
\text { 2. Feeling at risk in the capital } \\
\text { market marked "under } \\
\text { control"; } \\
\text { 3. Feeling at risk in a stock } \\
\text { market that has high } \\
\text { speculation. }\end{array}$ & $\begin{array}{l}\text { Likert } \\
1,2,3,4,5 \\
\text { (Preston } \\
\text { and } \\
\text { Colman, } \\
\text { 2000) }\end{array}$ \\
\hline 6. & Herding & $\begin{array}{l}\text { Herding is a condition in which } \\
\text { rational people begin to behave } \\
\text { irrationally by imitating other } \\
\text { people's judgments when making } \\
\text { decisions (Kumar \& Goyal, } \\
\text { 2015). }\end{array}$ & $\begin{array}{l}\text { 1. Investment decisions } \\
\text { depend on other people's } \\
\text { investment decisions. } \\
2 . \text { Will react quickly to } \\
\text { changes in other investors' } \\
\text { decisions. } \\
\text { 3. Prefer to buy shares if the } \\
\text { stock was in demand from the } \\
\text { beginning of trading. }\end{array}$ & $\begin{array}{l}\text { Likert } \\
1,2,3,4,5 \\
\text { (Preston } \\
\text { and } \\
\text { Colman, } \\
\text { 2000) }\end{array}$ \\
\hline
\end{tabular}

Source: Compiled from various sources, 2020

\section{RESULTS AND DISCUSSION}

The population of this research is customers who have opened Islamic stock accounts at Phintraco Sekuritas Semarang City Branch. The total sample used in this research is a number of 91 respondents who have filled out questionnaires that have been distributed online from September 1 to September 14, 2020, through the official group of Phintraco Sekuritas stock investors, here are the authors display the data collection results table in table 2:

Table 2 Data Collection Results

\begin{tabular}{lrr}
\hline Information & Total & Percentage \\
\hline Distributed questionnaires & 91 & $100 \%$ \\
\hline Unprocessed questionnaire & 0 & $0 \%$ \\
\hline Processable questionnaire & 91 & $100 \%$ \\
\hline Source: Primary data processed, 2020 & &
\end{tabular}


Guided by the table above, it can be concluded that from all the questionnaires distributed online, namely 91 questionnaires, all questionnaires were filled in completely and correctly by the respondent, which made 91 questionnaires (100\%) able to be processed. This research uses the SmartPLS 3.0 analysis tool where there are two tests. first, namely the outer model test or measurement model in which there is a validity test and a reliability test. Second, the inner model test or structural model that tests the effect of latent variables with their construct variables. Based on the research results, the value of outer loadings shows that the majority of constructs have a loading factor value above 0.70 and are significant (t-statistic $>\mathrm{t}$ table). In addition, the average variance extracted (AVE) shows that the endogenous latent variable of Islamic investor investment decisions has an AVE value of 0.585 so that it can be declared valid because the AVE value is $>0.50$. A number of these findings are briefly described in Table 3 and Table 4.

Table 3 Outer Loading

\begin{tabular}{|c|c|c|c|c|c|c|}
\hline & Anchoring & Availability & Herding & $\begin{array}{l}\text { Investment } \\
\text { Decision }\end{array}$ & Representativeness & $\begin{array}{c}\text { Risk } \\
\text { Perception }\end{array}$ \\
\hline $\mathrm{AC} 1$ & 0,814 & & & & & \\
\hline $\mathrm{AC} 2$ & 0,880 & & & & & \\
\hline $\mathrm{AC} 3$ & 0,800 & & & & & \\
\hline $\mathrm{AC} 4$ & 0,659 & & & & & \\
\hline AV1 & & 0,776 & & & & \\
\hline AV2 & & 0,788 & & & & \\
\hline AV3 & & 0,851 & & & & \\
\hline AV4 & & 0,798 & & & & \\
\hline AV5 & & 0,772 & & & & \\
\hline $\mathrm{H} 1$ & & & 0,829 & & & \\
\hline $\mathrm{H} 2$ & & & 0,854 & & & \\
\hline H3 & & & 0,826 & & & \\
\hline $\mathrm{H} 4$ & & & 0,757 & & & \\
\hline H5 & & & 0,771 & & & \\
\hline K1 & & & & 0,657 & & \\
\hline $\mathrm{K} 2$ & & & & 0,836 & & \\
\hline K3 & & & & 0,793 & & \\
\hline $\mathrm{K} 4$ & & & & 0,698 & & \\
\hline K5 & & & & 0,825 & & \\
\hline R1 & & & & & 0,748 & \\
\hline $\mathrm{R} 2$ & & & & & 0,813 & \\
\hline R3 & & & & & 0,767 & \\
\hline $\mathrm{R} 4$ & & & & & 0,952 & \\
\hline R5 & & & & & 0,878 & \\
\hline RP1 & & & & & & 0,928 \\
\hline RP2 & & & & & & 0,762 \\
\hline RP3 & & & & & & 0,938 \\
\hline RP4 & & & & & & 0,880 \\
\hline
\end{tabular}

Source: SmartPLS 3.0 output, 2020

Table 4 Average Variance Extracted (AVE)

\begin{tabular}{lcccc}
\hline & Cronbach's Alpha & rho_A & $\begin{array}{c}\text { Composite } \\
\text { Reliability }\end{array}$ & $\begin{array}{c}\text { Average Variance } \\
\text { Extracted (AVE) }\end{array}$ \\
\hline Anchoring & 0,801 & 0,796 & 0,870 & 0,628 \\
\hline Availability & 0,858 & 0,870 & 0,897 & 0,636 \\
\hline Herding & 0,874 & 0,899 & 0,904 & 0,654 \\
\hline Investment Decision & 0,823 & 0,840 & 0,875 & 0,585 \\
\hline Representativeness & 0,889 & 0,900 & 0,919 & 0,697 \\
\hline
\end{tabular}


THE EFFECT OF REPRESENTATIVENESS, AVAILABILITY, ANCHORING, RISK PERCEPTION, AND HERDING ON INVESTMENT DECISIONS SYARIAH INVESTORS

Rico Priandana Loris and Prabowo Yudo Jayanto

\begin{tabular}{lllll}
\hline Risk Perception & 0,904 & 0,956 & 0,932 & 0,774 \\
\hline Source: Smart
\end{tabular}

Source: SmartPLS 3.0 output, 2020

This value can be interpreted that the variability of the Islamic investor investment decision construct which can be explained by other constructs is $48 \%$ while $52 \%$ is explained by other factors outside of this study. According to Chin (1998), the R square values are 0.67 (strong), 0.33 (moderate) and 0.19 (weak). So, it can be concluded that the R-Square for endogenous latent variables (investment decisions) is moderate because it has an R-Square value of more than 0.33. A number of these findings are briefly described in this table.

Table 5 R Square

\begin{tabular}{lcc}
\hline & R Square & R Square Adjusted \\
\hline Keputusan Investasi & 0,484 & 0,453 \\
\hline
\end{tabular}

Source: SmartPLS 3.0 output, 2020

The results of hypothesis testing show multiple linear tests which indicate that representative, anchoring, risk perception, and herding affect Islamic investors' investment decisions in a positive direction. Meanwhile, availability has no effect on Islamic investor investment decisions. A number of these findings are briefly described in Table 6.

Table 6 Hypothesis Testing Results

\begin{tabular}{llcccc}
\hline No. & \multicolumn{1}{c}{ Hypothesis } & $\begin{array}{l}\text { Original } \\
\text { Sample }\end{array}$ & T- Statistics & P Values & Result \\
\hline 1 & $\begin{array}{l}\text { H1: Representative has a positive } \\
\text { effect on Islamic investor investment } \\
\text { decisions }\end{array}$ & 0.298 & 2,684 & 0.008 & $\begin{array}{c}\text { Hypothesis } \\
\text { Accepted }\end{array}$ \\
\hline 2 & $\begin{array}{l}\text { H2: Availability has a positive effect } \\
\text { on Islamic investor investment } \\
\text { decisions }\end{array}$ & & 0.004 & 0.030 & Hypothesis \\
Denied
\end{tabular}

Source: SmartPLS 3.0 output, 2020

\section{Representativeness Has A Positive Effect On Investment Decisions In Islamic Investors}

The path coefficient results show that the first hypothesis $\left(\mathrm{H}_{1}\right)$ which reveals representativeness positively influencing sharia investor investment decisions is accepted. The direction of the relationship between representativeness and investment decisions in Islamic investors is positive. It can be seen from these results which state that the majority of Islamic Phintraco Sekuritas Semarang investors tend to be exposed to representativeness behavior bias. Following the theory of behavioral finance which states that the bias is financial decision making, it makes individuals to include psychological aspects that can cause cognitive bias from illogical actions. This theory tries to explain investor irrationality and the decision-making process based on psychology (Subramaniam \& Velnampy, 2017). Investors when they are going to invest do not only look at the prospects for investment, the rate of return or risk to be obtained, but psychological factors also greatly determine investment decision making. In biased financial decision making, individuals involve psychological aspects that can cause 
deviations from rational behavior (Paramita \& Isbanah, 2018). Investors may mistake the good characteristics of a company (eg, quality products, reliable managers, high expected growth) as characteristics of a good investment. This stereotype will lead to cognitive errors because it shows that these "glamorous" companies are often bad-investment. Investors can also consider past returns to represent what they can expect in the future (Chen et al., 2011) This representativeness behavior bias causes sharia investors at Phintraco Sekuritas Semarang to behave irrationally or recklessly in making investment decisions.

Investors assume that the satisfactory past performance of stocks will continue in the future. Their assessment of information related to stock prices is not paid much attention and is not analyzed in detail so that investors often make the wrong decision. This means that when investors get information on the purchase price of shares, then the price matches their expectations, the investor will buy these shares directly. Representativeness behavior bias is a bias in financial behavior for decision making that only relies on past experiences that are considered capable of representing or guiding current investment decisions (Pompian, 2012). Research results are supported by research by Rasheed et al (2018), Khan, HH et al (2017), Waweru et al (2014), Rekik and Boujelbene (2013). However, these results are not in sync with the research of Diah Kurniawati and Sutrisno (2019) and Shah et al (2018).

\section{Availability Does Not Have A Positive Effect On Investment Decisions In Islamic Investors}

The path coefficient results show that the second hypothesis $(\mathrm{H} 2)$ which reveals availability positively affects the investment decisions of Islamic investors are rejected. It can be seen from these results which state that the Islamic investor Phintraco Sekuritas Semarang City does not have a tendency to be exposed to availability behaviour bias. Availability behaviour bias is one of the biases in financial behaviour. The availability behaviour bias is an investment decision that is formulated only prioritizing convenience and availability (the easiest and at the same time available to implement is the final decision (Pompian, 2012). However, even though the information is well available, Islamic investors at Phintraco Sekuritas Semarang City formulate investment decisions that are not swayed by the available information. In other words, investors try to anticipate risks that may arise by trying to analyze in detail the information obtained. Investors try to decide options from a number of alternatives available by managing the information obtained for the validity and reliability of the information received. Reliable and factual information obtained is the most important thing that can support the success of investors in making investment decisions. According to Pompian (2012), availability bias is a cognitive bias that can be minimized through financial and investment education. This is also supported by Phintraco Sekuritas Semarang City, who regularly educates its customers every Sunday. The results of the study are supported by research by Diah Kurniawati and Sutrisno (2019) and are not in line with the research of Rasheed et al (2018), Khan, HH et al (2017), Khan (2015), Ikram (2015)

\section{Anchoring Has A Positive Effect On Investment Decisions In Islamic Investors}

The output of the path coefficient shows that the third hypothesis (H3) which explains that anchoring positively affects the investment decisions of Islamic investors is accepted. The direction of the relationship between anchoring and Islamic investor investment decisions is positive. It can be seen from these results which state that the Islamic investors of Phintraco Sekuritas Semarang City have a tendency to be exposed to anchoring behaviour bias. In accordance with the theory of behavioural finance which explains that in the formulation of biased financial decisions, individuals are required to include psychological aspects that can cause cognitive bias from illogical actions. Investors with this anchoring behaviour tendency are included in the cognitive bias in financial behaviour. At first, the behaviour carried out by 
investors shows normal behaviour, because in making investment decisions based on facts that exist by observing the initial purchase price of the investment. However, there was an error in the information processing process, because the information that investors get regarding the purchase price of their investment will be used as a reference for investing and ignoring a number of new existing information. So when the latest facts in the field show a decline in investment performance and the selling price of investments owned by investors, investors will continue to believe that the selling price of their investments will increase in the future. The findings of this research are supported by research conducted by Luong, et al (2011), Muriithi (2014), Masomi and Ghayekhloo (2010), and Waweru et al (2014) that anchoring has a significant effect on investors' decisions. But not in line with Budiman's research (2020).

\section{Risk Perception Has A Positive Effect On Investment Decisions In Islamic Investors}

The path coefficient test shows that the fourth hypothesis (H4) which expresses risk perception positively influencing sharia investor investment decisions is accepted. The direction of the relationship between risk perception on Islamic investors' investment decisions is positive. This is explained through prospect theory which shows the behaviour of individuals in situations when they face uncertainty and risk. Through this research, it was found that the sharia investor Phintraco Sekuritas Semarang City tends to be a risk-taker type. A risk-taker is a type of investor who is willing to take risks or likes risk. The tendency of the risk-taker investor type is that investors can have control over the amount of risk that can be borne. Investors tend to have the capability in selecting and deciding the risks of an investment, from low to high risk. This is in line with the Theory of Planned Behavior developed by Ajzen (1985) which is able to verify the effect of perceived investment risk on investment decisions. This theory states that someone acts based on their interest. One of the factors that determine interest is perceived behaviour control. This study shows that the perception of investment risk is able to influence Phintraco Sekuritas Islamic investors in making investment decisions. The findings of this research prove that the better the perception of investment risk, the higher the interest in investing will be made by investors. The findings of this study are in sync with research from Baghani \& Sedaghat (2016), Aren \& Zhengin (2016) and are not in line with research by Khairunizam and Yuyun Isbanah (2019), Alquraan et al (2016), and Pradikasari \& Isbanah (2018).

\section{Herding Positively to Investment Decision on the Investor Sharia}

The output of the path coefficient shows that the fifth hypothesis (H5) which states that herding has a positive effect on Islamic investor investment decisions is accepted. The direction of the relationship between herding and Islamic investor investment decisions is positive. It can be seen from these results which state that the Islamic investor Phintraco Sekuritas Semarang City has a tendency to be exposed to herding behaviour bias. This is because investors tend to rely more on other people's decisions in making their investment decisions. In this case, the Islamic investor Phintraco Sekuritas Semarang City tends to make decisions based on majority decisions, thus investors only depend on collective information from other investors which is often shared in the Phintraco Sekuritas investor community group. Referring to other people's decisions, investors react more quickly to changes in other people's decisions in investing because they think that other people's investment choices are better than their own desires.

In accordance with the theory of behavioural finance which explains that biased financial decision making, individuals are required to include psychological aspects that can cause cognitive bias from irrational behaviour. Investors tend to imitate or follow the behaviour of others, regardless of whether the actions of others are rational or irrational. The findings of this research are in sync with the research of Vijaya (2016), Ngoc (2013), Luong \& Thi Thu 
Ha (2011) and Khairunizam \& Yuyun Isbanah (2019) which reveal that herding behaviour positively influences investment decisions. However, it is not in line with the research of Alquraan et al, (2016) and Setiawan et al. (2018).

\section{CONCLUSIONS AND SUGGESTION}

Based on the research results that have been explained, the researcher found that the behaviour of representativeness anchoring, risk perception, and herding positively has a significant effect on investment decisions of Islamic investors Phintraco Sekuritas Semarang City Branch. Meanwhile, availability behaviour bias has no effect on investment decisions of Sharia Phintraco Sekuritas Semarang investors. The suggestion in this research is first, for the next research, it is hoped that it will be able to increase the research sample that will be used. This is because the sample is only limited to Islamic investors in one securities company, namely Phintraco Sekuritas in the city of Semarang. In addition, researchers suggest including four other factors in behavioural finance (heuristic factors, prospect factors, herding factors and market factors) which in this study only used heuristic factors, prospect factors, and herding factors. Second, for investors, based on the results of research that shows that representativeness, anchoring, risk perception and herding bias behaviour affects investment decisions in Islamic investors Phintraco Sekuritas Semarang City Branch, researchers suggest being more careful in making decisions, because biased behaviour can lead to irrational and wrong decisions. So this requires in-depth analysis, considering various existing risk aspects and enriching oneself with financial literacy to get the expected return. 
THE EFFECT OF REPRESENTATIVENESS, AVAILABILITY, ANCHORING, RISK PERCEPTION, AND HERDING ON INVESTMENT DECISIONS SYARIAH INVESTORS

Rico Priandana Loris and Prabowo Yudo Jayanto

\section{REFERENCES}

Ajzen, I. (1985). From Intentions to Actions: A Theory of Planned Behavior. Action Control, 11-39.

Alquraan, T., Alqisie, A., \& Shorafa, A. Al. (2016). Do Behavioral Finance Factors influence Stock Investment Decisions of Individual Investors? (Evidences from Saudi Stock Market). Journal of American Science, 12(9), 72-82. https://doi.org/doi:10.7537/marsjas120916.12.

Aren, S., \& Zengin, A. N. (2016). Influence of Financial Literacy and Risk Perception on Choice of Investment. Procedia - Social and Behavioral Sciences, 235(November 2016), 656-663. https://doi.org/10.1016/j.sbspro.2016.11.047

Baghani, M., \& Sedaghat, P. (2016). Effect of Risk Perception and Risk Tolerance on Investors' Decision Making in Tehran Stock Exchange. International Academic Journal of Accounting and Financial Management, 3(9), 45-53. Retrieved from www.iaiest.com

Budiman, J., \& Ervina. (2020). Pendekatan Perilaku Keuangan Terhadap Keputusan Investasi Emas. Jurnal Profit, 14(1), 63-68. https://doi.org/10.21776/ub.profit.2020.014.01.7

Chen, G., Kim, K. A., Nofsinger, J. R., \& Rui, O. M. (2011). Trading Performance, Disposition Effect, Overconfidence, Representativeness Bias, and Experience of Emerging Market Investors. SSRN Electronic Journal, (January). https://doi.org/10.2139/ssrn.957504

Darmawan, T., \& Anwar, S. (2019). Analisis Faktor-Faktor yang Memengaruhi Keputusan Investasi di Pasar Modal Syariah. Jurnal Middle East and Islamic Studies, 6(2).

Hadi, N. (2013). “Pasar Modal.” Yogyakarta: Graha Ilmu.

Ikram, Z. (2016). An Empirical Investigation on Behavioral Determinants on Impact on Investment Decision Making, Moderating Role of Locus of Control. Journal of Poverty, Investment and Development, 26, 44-50.

Kartini, K., \& Nugraha, N. F. (2015). Pengaruh Illusions of Control, Overconfidence Dan Emotion Terhadap Pengambilan Keputusan Investasi Pada Investor Di Yogyakarta. Ajie, 4(2), 114-122. https://doi.org/10.20885/ajie.vol4.iss2.art6

Khairunizam, \& Isbanah, Y. (2019). "Pengaruh Financial Literacy Dan Behavioral Finance Factors Terhadap Keputusan Investasi." Jurnal Ilmu Manajemen, 7(2), 516-528. Retrieved from www.ekonomisyariah.org

Khan, H. H., Naz, I., Qureshi, F., \& Ghafoor, A. (2017). "Heuristics and Stock Buying Decision: Evidence From Malaysian and Pakistani Stock Markets." Borsa Istanbul Review, 17(2), 97-110. https://doi.org/10.1016/j.bir.2016.12.002.

Kumar, S., \& Goyal, N. (2015). Behavioural Biases in Investment Decision Making - A Systematic Literature Review. Qualitative Research in Financial Markets, 7(1), 88-108. https://doi.org/10.1108/QRFM-07-2014-0022. 
Kurniawati, D., \& Sutrisno, S. (2019). The Benchmark of Investor Decisions To Invest in the Initial Public Offering (IPO). Riset Akuntansi Dan Keuangan Indonesia, 4(2), 166-176. https://doi.org/10.23917/reaksi.v4i2.8543.

Nasional, D. S. (2003). Fatwa Dewan Syariah Nasional No. 40. Jakarta

Paramita, R. S., \& Isbanah, Y. (2018). Bias Kognitif Dan Kepribadian Individu: Studi Perilaku Investor Muda Di Surabaya. Jurnal Riset Manajemen Sains Indonesia (JRMSI) |, 9(2), 2301-8313. https://doi.org/10.21009/JRMSI.

Pompian, M. M. (2012). Behavioral Finance and Investor Types: Managing Behavior to Make Better Investment Decisions. In SSRN Electronic Journal. https://doi.org/10.2139/ssrn.255778.

Prabawa, B., Nasri, J., \& Sulistiyo, M. D. (2015). Prediksi Harga Saham Dengan Menggunakan Metode Autoregressive Dan Algoritma Kelelawar. E-Proceeding of Engineering, 2(1), 1696-1704.

Pradikasari, E., \& Isbanah, Y. (2018). Pengaruh Financial Literacy, Illusion of Control, Overconfidence, Risk Tolerance, dan Risk Perception Terhadap Keputusan Investasi Pada Mahasiswa di Kota Surabaya. Jurnal Ilmu Manajemen (JIM), 6(4), 424-434.

Preston, C. C., \& Colman, A. M. (2000). Optimal Number of Response Categories in Rating Scales: Reliability, Validity, Discriminating power, and Respondent Preferences. Acta Psychologica, 104(1), 1-15. https://doi.org/10.1016/S0001-6918(99)00050-5.

Rakhmatulloh, A. D., \& Asandimitra, N. (2019). Pengaruh Overconfidence, Accounting Information, Dan Behavioural Motivation Terhadap Keputusan Investasi Di Kota Surabaya. Jurnal Ilmu Manajemen (JIM), 7(3), 796-806.

Rasheed, M. H., Rafique, A., Zahid, T., \& Akhtar, M. W. (2018). "Factors Influencing Investor's Decision Making in Pakistan: Moderating The Role of Locus of Control." https://doi.org/https://doi.org/10.1108/ RBF-05-2016-0028.

Ritter, J. R. (2003). Behavioral Finance. Pacific Basin Finance Journal, 11(4), 429-437. https://doi.org/10.1016/S0927-538X(03)00048-9.

Septyato, D., \& Dewanto, I. J. (2016). Model Perilaku Syariah Dalam Pengambilan Keputusan Investasi Pada Investor Muslim Di Bursa Efek Indonesia. Prosiding Seminar Nasional, 425-437. Retrieved from www.jp.feb.unsoed.ac.id/index.php/sca1/article/viewFile/306/311.

Setiawan, Y. C., Atahau, A. D. R., \& Robiyanto, R. (2018). Cognitive Dissonance Bias, Overconfidence Bias dan Herding Bias dalam Pengambilan Keputusan Investasi Saham. AFRE (Accounting and Financial Review), 1(1), 17-25. https://doi.org/10.26905/afr.v1i1.1745.

Shefrin, H. (2007). Behavioral Corporate Finance : Decisions That Create Value. New York: McGraw-Hill. 
Silviyani, N. L. N. T., Sujana, E., \& Adiputra, I. M. P. (2014). "Pengaruh Likuiditas Perdagangan Saham Dan Kapitalisasi Pasar Terhadap Return Saham Perusahaan Yang Berada Pada Indeks Lq45 Di Bursa Efek Indonesia Periode Tahun 2009-2013. E-Journal S1 Ak Universitas Pendidikan Ganesha, 2(1), 1-11.

Sina, P. (2014). Representativeness Bias Dan Demografi Dalam Membuat Keputusan Keuangan. Jurnal Manajemen Maranatha, 14(1).

Subash, R. (2012). Role of Behavioral Finance in Portfolio Investment Decisions: Evidence from India. Faculty of Social Science Institute of Economic Studies, 8-9. Retrieved from http://ies.fsv.cuni.cz/default/file/download/id/20803

Subramaniam, A., \& Velnampy, T. (2017). The Role of Behavioural Factors in the Investment Decisions of Household Investors. International Journal of Accounting and Financial Reporting, 7(1), 392. https://doi.org/10.5296/ijafr.v7i1.11421.

Supramono, Nastiti, P. K. Y., \& Damayanti, T. W. (2018). “Keuangan Berbasis Perilaku” (1st ed.). Yogyakarta: Penerbit ANDI.

Vijaya, E. (2016). An Exploratory Analysis on Behavioural Pattern of Retail Equity Investors. ACADEMICIA: An International Multidisciplinary Research Journal, 6(12), 93. https://doi.org/10.5958/2249-7137.2016.00098.7.

Wareza, M. (2019). Hari Terakhir Bursa 2019, Investor Pasar Modal Capai 2,4 Juta. Retrieved February 16, 2020, from CNBC Indonesia website: https://www.cnbcindonesia.com/market/20191230142312-17-126472/hari-terakhirbursa-2019-investor-pasar-modal-capai-24-juta.

Wulandari, D. A., \& Iramani, R. (2014). Studi Experienced Regret, Risk Tolerance, Overconfidance dan Risk Perception pada Pengambilan Keputusan Investasi. Journal of Business and Banking, 4(1), 55. https://doi.org/10.14414/jbb.v4i1.293.

Yafiz, M. (2008). "Saham Dan Pasar Modal Syariah: Konsep, Sejarah Dan Perkembangannya.” Miqot: Jurnal Ilmu-Ilmu Keislaman, 32(2), 232-246. 